Полич С. Б.

ИНСТИТУТ СУДЕБНОГО ПРИМИРЕНИА: НАУЧНЫЕ И ПРАКТИЧЕСКИЕ ПРОГНОЗЫ

\title{
Polich S.B. \\ INSTITUTE OF JUDICIAL RECONCILIATION: SCIENTIFIC AND PRACTICAL FORECASTS
}

\begin{abstract}
В статье обозначается судебное примирение как один из новых институтов посредничества, утверждается, что судебный примиритель, как профессиональный посредник, одновременно «занимается» судебной деятельностью, априори утверждается, что судья, пребывающий в отставке в силу соответствующего статуса является именно профессиональным посредником, предлагается квалифицировать полномочия судебного примирителя как судебную деятельность.

Ключевые слова: посредничество как гражданско-правовая сделка, судебное примирение как один из институтов посредничества, судебное примирение как иная разновидность судебной деятельности, судебное примирение как «процедурный способ» урегулирования экономических конфликтов.
\end{abstract}

The article denotes judicial conciliation as one of the new institutions of mediation, it is argued that a judicial conciliator, as a professional mediator, is simultaneously "engaged" in judicial activity, a priori it is argued that a retired judge by virtue of his status is precisely a professional mediator, it is proposed to qualify the powers judicial conciliator as judicial activity.

Keywords: mediation as a civil law transaction, judicial conciliation as one of the institutions of mediation, judicial conciliation as another type of judicial activity, judicial conciliation as a "procedural way" of resolving economic conflicts.

Текущий период развития гражданского общества в Российской Федерации характеризуется активным внедрением и развитием альтернативных способов урегулирования экономических конфликтов.

По этому благодатному пути «идет» современный российский законодатель.

С 2011 года в Российской Федерации применяется Федеральный закон от 27.07.2010 № 193-Ф3 «Об альтернативной процедуре урегулирования споров с участием посредника (процедуре медиации) - (далее по тексту статьи - Закон о медиации), в котором также с 2019 года обозначена фигура судебного примирителя.

Таким образом, наряду с профессиональными медиаторами, «появились» судебные примирители, которыми с делегированием им соответствующих полномочий Верховным Судом Российской Федерации «стали», в том числе, судьи, пребывающие в отставке.

В рамках этой статьи попытаемся ответить на два вопроса: в чем особенность судебного примирения как одного из разновидностей альтернативного способа урегулирования экономических конфликтов и, - как следовало было бы охарактеризовать институт судебного примирения - как разновидность посредничества, как один из видов медиации либо это одно из направлений профессиональной судебной деятельности?

Из комплексного анализа действующего процессуального законодательства [2] следует, что судебное примирение является не чем иным, как разновидностью посредничества как обычной гражданскоправовой сделки.

Посредничество является чрезвычайно распространенной правовой и внеправовой формой взаимоотношений между людьми.

В одних случаях посредничество облечено в форму финансовой услуги, в других случаях - в форму организационнораспорядительных действий, в тетьих случаях - в форму правовой услуги... И таких форм и разновидностей посредничества можно назвать бесчисленное множество, а перечислить и обозначить все абсолютно невозможно [1, с. 65]. 
Итак, судебный примиритель является обыкновенным посредником, поскольку это правило прямо следует из положений статей 153.1 Гражданского процессуального кодекса российской Федерации, 138.2 Арбитражного процессуального кодекса Российской Федерации, 137.3 Кодекса административного судопроизводства Российской Федерации.

Одновременно, судебное примирение. равно как и медиация (но только проводимая после передачи экономического конфликта на рассмотрение государственного суда) - это так называемый «процессуальный способ» урегулирования экономических конфликтов.

Попытаемся обосновать заявленный тезис.

Не секрет, что в мировой практике существует несколько десятков видов примирительных процедур [2, с. 103], а сами по себе институты медиации и судебного примирения заимствованы российским правопорядком из французского права.

Заметим, что во Французском гражданском процессуальном кодексе (Code de Procedure Civile) какие-то существенные процедурные отличия между этими альтернативными способами разрешения споров отсутствуют, поэтому смеем утверждать, что сами по себе процедуры mediation (медиация) и conciliation (судебное примирение) фактически равнозначны [4].

Предпринимаемые в современной отечественной юридической литературе попытки «разграничить» медиацию и судебное примирение не умаляют тождественность и «правовую близость» этих альтернативных способов урегулирования экономических конфликтов.

Из сказанного следует, что судебное примирение - это не что иное как процедурный (так называемый «процессуальный») способ урегулирования экономических конфликтов.

В Регламенте проведения судебного примирения, утвержденного Постановле- нием Пленума Верховного Суда Российской Федерации от 31 октября 2019 года, мы «видим» судебное примирение в качестве примирительной процедуры, достаточно проанализировать характер статей $16,17,18,19,20,21,22 \ldots$

Далее обозначим - эта примирительная процедура по своему правовому содержанию «напоминает» характер судебной деятельности - и по аналогии представляет не что иное, как «помощь» действующему судье в примирении сторон экономического конфликта.

Ранее мы утверждали, что медиация это также разновидность посредничества, и она объективно может составлять ежегодно лишь от 0,002\% до 0,004\% всех посреднических сделок в Российской Федерации. [1, с. 65].

Вместе с тем, в целях анализа практического применения института судебного примирения сложно оперировать даже какой-либо статистикой, поскольку представить судью в отставке, «добровольно» взявшему на себя роль посредника в каких либо реальной жизненной ситуации, просто невозможно!

Итак, социальные и экономические условия для развития института посредничества в России созданы очень давно. Первые итоги применения Закона о медиации показали, что требует серьезного осознания институт посредничества как мощный инструмент снижения уровня конфликтности общественных процессов и явлений. А сама по себе медиация сможет обрести «новое рождение» лишь в случае обозначения ее в качестве «процессуального способа» урегулирования экономических конфликтов.

Позволим взять на себя смелость и прогнозировать такое развитие и в отношении института судебного примирения!

Полагаем, что «временная судьба» института судебного примирения напрямую обусловлена тенденциями увеличения (снижения) конфликтности российского общества.

\section{Литература}

1. Полич С.Б. Медиация как способ урегулирования экономических конфликтов. Достигнут ли ожидаемый правовой эффект?// Проблемы права № 1(60)/ 2017.

2. Полич С.Б. Полуэктова Е.И. Новеллы медиации и перспективы ее применения// Арбитражная практика. апрель 2011. № 4.

3. Под фразой «комплексный анализ» процессуального законодательства понимается исследование и изучение трех действующих процессуальных законов гражданско-правового толка, а именно Гражданского процессуального кодекса Российской Федерации, Арбитражного процессуального кодекса Российской Федерации и Кодекса административного судопроизводства Российской Федерации.

4. www.legifrance.gonv.fr/codes/article_ec/LEGARTI000006410643 (дата обращения 22.09.2020). 


\section{References}

1. Polich S.B. Mediatsiya kak sposob uregulirovaniya ekonomicheskikh konfliktov. Dostignut li ozhidayemyy pravovoy effekt?// Problemy prava № 1(60)/ 2017

2. Polich S.B. Poluektova Ye.I. Novelly mediatsii i perspektivy yeye primeneniya// Arbitrazhnaya praktika. aprel' 2011. № 4.

3. Pod frazoy «kompleksnyy analiz» protsessual'nogo zakonodatel'stva ponimayetsya issledovaniye i izucheniye trekh deystvuyushchikh protsessual'nykh zakonov grazhdansko-pravovogo tolka, a imenno Grazhdanskogo protsessual'nogo kodeksa Rossiyskoy Federatsii, Arbitrazhnogo protsessual'nogo kodeksa Rossiyskoy Federatsii i Kodeksa administrativnogo sudoproizvodstva Rossiyskoy Federatsii. 4. www.legifrance.gonv.fr/codes/article_ec/LEGARTI000006410643 (data obrashcheniya 22.09.2020)

Полич Светлана Байрамовна, кандидат юридических наук, доцент, доцент кафедры гражданского права и гражданского судопроизводства, Южно-Уральский государственный университет. 454080, г. Челябинск, пр. Ленина, 76. E-mail: polichsb@susu.ru

POLICH Svetlana Bayramovna, Candidate of Legal Sciences, Associate Professor, Associate Professor of the Department of Civil Law and Civil Procedure, South Ural State University. 454080, Chelyabinsk, Lenin Ave., 76. E-mail: polichsb@susu.ru 